\title{
$\widehat{A}$ Madridge \\ madridge Journal of Dentistry and Oral Surgery \\ Interconnecting Scientific World
}

Research Article

Open Access

\section{In Vivo Biocompatibility of Four Endodontic Sealers: A Comparative Study}

\author{
Rania M Khashaba ${ }^{1,2}$, and Mervet M Moussa ${ }^{3,4 \star}$ \\ ${ }^{1}$ Department Oral Biology, Georgia Health Sciences University, Augusta, GA, USA \\ ${ }^{2}$ Department of Biomaterials, Misr International University (M.I.U), Cairo, Egypt \\ ${ }^{3}$ Department of Oral Pathology, Faculty of Oral E Dental Medicine, Cairo University, Cairo, Egypt \\ ${ }^{4}$ Departmentof Basic Dental Science, College of Dentistry, Princess Nourah Bint Abdul Rahman University, Riyadh, Saudi Arabia
}

\section{Article Info}

\author{
*Corresponding author: \\ Mervet M Moussa \\ Department of Basic Dental Science \\ College of Dentistry, Princess Nourah Bint \\ Abdul Rahman University \\ Riyadh, Saudi Arabia \\ Tel: 966568519694 \\ E-mail: drmervet@yahoo.com
}

Received: July 19, 2016

Accepted: August 24, 2016

Published: August 29, 2016

Citation: Khashaba RM, Moussa MM. In Vivo Biocompatibility of Four Endodontic Sealers: A Comparative Study. Madridge J Dent Oral Surg. 2016; 1(1): 4-12.

doi: 10.18689/mjdl-1000102

\section{Copyright: @ 2016 The Author(s). This work is licensed under a Creative Commons Attribution 4.0 International License, which permits unrestricted use, distribution, and reproduction in any medium, provided the original work is properly cited.}

Published by Madridge Publishers

\begin{abstract}
The aim of this study was to compare the biocompatibility of two new calcium phosphate - based root canal sealers (CPC-I, CPC-II) with a commercially available zinc oxide eugenol based-sealer [Pulp canal sealer EWT (PCS EWT)] and Sealapex after implantation in the subcutaneous tissue of rats. Sterile polyethylene tubes were filled with the test materials. The tubes were implanted in the dorsum of male rats and after 1, 2, 4 and 8 weeks, the animals were killed, obtaining 5 specimens for each sealer. Empty tubes were used as negative control. Presence of inflammation, predominant cell types, and thickness of fibrous connective tissue adjacent to each inserted sample were recorded. At week 1 , all sealers caused similar inflammatory reactions in the connective tissue of the animals, with most specimens presenting a moderate to intense chronic inflammatory reaction. After 2 weeks, CPC-II and (PCS EWT) showed a severe inflammatory reaction with presence of acute inflammatory cells, while CPC-I and Sealapex induced mild and moderate inflammatory reactions respectively. After 4 weeks, connective tissue in contact with CPC-I and Sealapex was more organized, while the tissue close to CPC-II and (PCS EWT) showed a moderate inflammatory reaction and had similar results to each other. After 8 weeks, mild inflammatory reactions were observed for CPC-I, (PCS EWT), and Seal apex. CPC-I induced the lowest inflammatory response at all evaluation periods, only CPC-II did not show a decrease in the inflammatory reaction over time. CPC-I sealer can be assigned a favorable biocompatibility level based on the study's histological findings.
\end{abstract}

Keywords: Endodontics; Biocompatibility; Calcium-Phosphate Based Sealers; Pulp Canal sealer; Seal Apex.

\section{Introduction}

Endodontic therapy requires removal of the pulp of the tooth followed by obturating the resulting root canal spaces. Generally, these spaces are filled with an adaptable core material coated with a sealer to assure an adequate barrier to bacterial ingress from the oral cavity over time. Both the core material and sealer interface with living tissue at the apex of the root of the tooth [1]. Successful healing of periapical tissues after endodontic therapy depends in part on the chemical composition and physical properties of the obturating materials and the extent of any degradation and release of components from these materials into the periapical tissues. 
The biological properties of sealers are particularly important because they may be expressed slightly past the apex of the root into the periapical space during obturation [2]. Extrusion of sealers may induce a foreign-body reaction that delays or prevents healing [3].

Most currently used root canal sealers are zinc- and eugenol- based materials, resin, glass ionomer, silicone and calcium hydroxide-based endodontic sealers are available as well [4-7].

Resin -based sealers are increasingly gaining popularity but studies have demonstrated that some of the sealers present toxicity and mutagenicity [8-9].

A calcium hydroxide-based sealer, Sealapex shows recognized biocompatibility and preliminary clinical data yielding promising results [10-13]. More recently the manufacturer has modified its formulation by adding bismuth trioxide to improve its radiopacity and to increase its shelf life [14]. The alterations in the original formulation could have affected negatively the tissue compatibility of this material. One of the commonly accepted definitions of biocompatibility includes the appropriate biological interactions between the host, the material and its expected function during a specific application. If a material is biocompatible, these three components should be in harmony [15].

It is well known that calcium phosphate cement (CPC) has biocompatibility because its composition is almost identical to that of tooth and bone mineral $[16,17]$. Its biocompatibility makes the material useful in applications in which the cement is in contact with the vital tissues [18]. Therefore, it has been suggested as a useful material for endodontic therapy $[19,20]$. Biocompatibility is one of the most important properties of root canal filling materials since the release of certain substances by the sealers may generate different reactions in the periapical tissues [21-23].

A simple, preferred method of testing the biocompatibility of endodontic sealers is the implantation of the material into the subcutaneous connective tissue of rats. The irritating effect of the materials can beevaluated via the histopathological examination of tissue response around the implants. Various test methods have been performed with many endodontic materials to evaluate their biocompatibility [24].

Recently, new calcium phosphate-based sealers have been developed and their biological properties in terms of cytotoxicity, tested physicochemical properties had been previously investigated [25]. These materials harden into cements when mixed with polymeric acids. There has not been any experimental animal study to assess these root canal sealer's biocompatibility in comparison with other materials yet.

Thus the aim of this study was to compare the biocompatibility of four root canal sealers with different chemical compositions, two newly developed calcium phosphate- based root canal sealers (CPC- I, CPC- II.) a zinc oxide-eugenol based Pulp canal sealer EWT (PCS EWT] and a calcium hydroxide-based sealer a new formulation of (Seal apex) after implanting them in the subcutaneous tissue of rats.

\section{Materials and Methods}

\section{Preparation of calcium phosphate cement powder}

Tetra calcium phosphate powder was synthesized from a solid state reaction between calcium hydrogen orthophosphate anhydrous $\left(\mathrm{CaHPO}_{4}\right)$ and calcium carbonate, then ground and sieved to obtain an average particle size of $1 \mu$ to $80 \mu$. Di calcium phosphate di hydrate powder (DCPD) was obtained from mono calcium phosphate and calcium oxide, which were crushed separately in an agate mortar to obtain an average particle size of $80 \mu$. Tri calcium phosphate $\mathrm{Ca}_{3}\left(\mathrm{PO}_{4}\right)_{2}$ was prepared by a crystallization method from aqueous solutions of $0.9 \mathrm{M}$ calcium nitrate $\left(\mathrm{Ca}\left(\mathrm{NO}_{3}\right)_{2} \cdot 4 \mathrm{H}_{2} \mathrm{O}\right)$ and $0.6 \mathrm{M}$ ammonium phosphate $\left(\mathrm{NH}_{4}\right) 2 \mathrm{HPO}_{4^{\prime}}$ which were simultaneously mixed. The reaction $\mathrm{pH}$ was maintained between 5 and 6 by the addition of ammonia solution.

The precipitated powder was stored for $24 \mathrm{hr}$ at room temperature, then washed with deionized water and lyophilized. The subsequent calcinations of the resulting powders were obtained at $900^{\circ} \mathrm{C}$ for over $1 \mathrm{hr}$. The tetra calcium phosphate, di calcium phosphate di hydrate and tri calcium phosphate were then mixed at a molar ratio 1:1:1 in a blender(Dynamics Corporation of America, New Hartford, CT) to form the CPC powder.

\section{Preparation of aqueous solution of liquids}

\section{Two types of liquids were prepared as follows:}

1) $35 \%(w / w)$ aqueous solution of poly methyl vinyl ether maleic acid was prepared by dissolving 35 grams of poly methyl vinyl ether maleic anhydride (PMVE-MA) copolymer (MW 50,000) in $100 \mathrm{~mL}$ of distilled water at $60^{\circ} \mathrm{C}$ for 24 hours in a shaker incubator.

2) $10 \%(w / w)$ aqueous solution of poly acrylic acid (PAA) was prepared ( $2 \mathrm{~mL}$ of PAA solution was added to $2 \mathrm{ml}$ of $10 \%$ water).

\section{Preparation of the calcium phosphates based root canal sealers}

CPC powder ( $60 \mathrm{wt} \%$ tetra calcium phosphate $+30 \mathrm{wt} \%$ di calcium phosphate dehydrate $+10 \mathrm{wt} \%$ tri calcium phosphate) individually mixed with liquid(1) formed of $35 \%(\mathrm{w} / \mathrm{w})$ aqueous solution of poly methyl vinyl ether maleic acid in a ratio of $4: 1$ to obtain CPC-I.

CPC powder (60 wt\% tetra calcium phosphate $+30 \mathrm{wt} \% \mathrm{di}$ calcium phosphate dehydrate $+10 \mathrm{wt} \%$ tri calcium phosphate) individually mixed with liquid(2) formed of $10 \%(\mathrm{w} / \mathrm{w})$ aqueous solution of poly acrylic acid in a ratio of 4:1 to obtain CPC-II.

Pulp canal sealer EWT (PCS EWT); Kerr, Detroit, M, and Sealapex (Kerr, Sybron Dental Specialties, Glendora, CA) were prepared in the manner advised by the manufacturers' instructions for clinical use. Table 1 shows the sealers used and their composition. 


\begin{tabular}{|c|c|c|c|}
\hline Material & Composition & Trade Name & \\
\hline $\begin{array}{l}\text { Calcium } \\
\text { hydrogen } \\
\text { orthophosphate } \\
\text { anhydrous }\end{array}$ & & & $\begin{array}{l}\text { Mallinckrodt } \\
\text { Baker, Inc. } \\
\text { Phillipsburg, NJ, } \\
\text { USA }\end{array}$ \\
\hline $\begin{array}{l}\text { Calcium } \\
\text { carbonate }\end{array}$ & & & $\begin{array}{l}\text { Mallinckrodt } \\
\text { Baker, Inc. } \\
\text { Phillipsburg, NJ, } \\
\text { USA }\end{array}$ \\
\hline $\begin{array}{l}\text { Monocalcium } \\
\text { phosphate } \\
\text { monobasic } \\
\text { (MCPM) }\end{array}$ & & $\begin{array}{l}\text { Calcium Phosphate } \\
\text { Monobasic }\end{array}$ & $\begin{array}{l}\text { Sigma Chemical } \\
\text { Laboratories, St. } \\
\text { Louis, MO, USA }\end{array}$ \\
\hline Calcium oxide & & & $\begin{array}{l}\text { Adwic } \\
\text { Laboratory } \\
\text { Chemicals Cairo, } \\
\text { Egypt }\end{array}$ \\
\hline Calcium nitrate & $\begin{array}{l}\mathrm{Ca}\left(\mathrm{NO}_{3}\right)_{2} \cdot 4 \mathrm{H}_{2} \mathrm{O} \\
\mathrm{FW} 236.15\end{array}$ & & $\begin{array}{l}\text { Sigma Chemical } \\
\text { Laboratories, St. } \\
\text { Louis, MO, USA }\end{array}$ \\
\hline $\begin{array}{l}\text { Ammonium } \\
\text { phosphate }\end{array}$ & $\begin{array}{l}\left(\mathrm{NH}_{4}\right)_{2} \mathrm{HPO}_{4} \\
\mathrm{FW} 132.06\end{array}$ & & $\begin{array}{l}\text { Sigma Chemical } \\
\text { Laboratories, St. } \\
\text { Louis, MO, USA }\end{array}$ \\
\hline $\begin{array}{l}\text { Polymethyl vinyl } \\
\text { ether maleic } \\
\text { anhydrate } \\
\text { copolymer } \\
\text { (PMVE-Ma) }\end{array}$ & & $\begin{array}{l}\text { For preparation of } \\
35 \% \text { aqueous } \\
\text { solution of } \\
\text { polymethyl vinyl } \\
\text { ether maleic acid }\end{array}$ & $\begin{array}{l}\text { Sigma Chemical } \\
\text { Laboratories, St. } \\
\text { Louis, MO, USA }\end{array}$ \\
\hline Polyacrylic acid & $\begin{array}{l}\text { Liquid:aqueous } \\
\text { solution of } \\
\text { polyacrylic acid and } \\
\text { itaconic acid, tartaric } \\
\text { acid as stabilizer } \\
\text { (70\% water, } 30 \% \\
\text { polyacrylic acid) }\end{array}$ & G.C.R & $\begin{array}{l}\text { G.C.R Advanced } \\
\text { Research Inc., } \\
\text { Dental division } \\
\text { Leeds, England }\end{array}$ \\
\hline $\begin{array}{l}\text { Pulp canal sealer } \\
\text { [PCS EWT] }\end{array}$ & $\begin{array}{l}\text { Powder: Zinc Oxide, } \\
\text { Precipitated } \\
\text { molecular silver, Oleo } \\
\text { resins, Thymoliodide } \\
\text { Liquid: Oil of cloves, } \\
\text { Canada balsam }\end{array}$ & & $\begin{array}{l}\text { Sybron Endo, } \\
\text { CA,USA }\end{array}$ \\
\hline Sealapex & $\begin{array}{l}\text { Catalyst: Isobutyl } \\
\text { salicylate resin, } \\
\text { fumed silica (silicon } \\
\text { dioxide), bismuth } \\
\text { trioxide, titanium } \\
\text { dioxide pigment } \\
\text { Base: N-ethyl toluene } \\
\text { solfanamide resin, } \\
\text { fumed silica ( silicon } \\
\text { dioxide ), zinc oxide, } \\
\text { calcium oxide }\end{array}$ & & $\begin{array}{l}\text { Sybron Endo, } \\
\text { CA,USA }\end{array}$ \\
\hline
\end{tabular}

Table 1: Composition of the materials used in this study and their manufacturers

The experimental protocol was ethically approved by the Institutional Animal Care and Use Committee at the Medical College of Georgia (2015/ A18). All procedures and animal care was carried out in accordance with the guidelines laid down by the National Institute of health, U.S. Public Health Service Policy on Human Care and Use of laboratory animals [26].

Eighty white male Sprague-Dawley rats (Rattus Novergicus albinus) 3-4 months weighing between 200 to $250 \mathrm{~g}$ obtained commercially and given standard pellets and water ad libitum were used in this study. The specimens were divided into four groups of five animals each for an experimental period of 1,2 ,
4 , and 8 weeks respectively. All tested materials were loaded into autoclaved polyethylene carriers (polytetrafluoroethylene, Du Pont, Habia, Knivsta, Sweden) $5 \mathrm{~mm}$ long with $1.5 \mathrm{~mm}$ inner diameter and $2 \mathrm{~mm}$ outer diameter. One of the tube ends was closed by heat to prevent the sealer from extruding. The polyethylene tubes were filled with freshly mixed sealers by means of a paper cone compatible with the diameter of tubes, ensuring that there were no empty spaces and that the sealer did not overflow. The animals were anesthetized by intramuscular administration of a rodent anesthesia cocktail $1.5 \mathrm{ml}$ Ketamine HCL (100 mg/ml), $1.5 \mathrm{ml}$ xylazine HCl (20 mg/ $\mathrm{ml})$ and $0.5 \mathrm{ml}$ acepromazine $(10 \mathrm{mg} / \mathrm{ml}) 0.2-0.5 \mathrm{ml} / 100 \mathrm{~g}$ of animal weight and stabilized on a surgical table. The back of the animal was shaved and disinfected with $5 \%$ iodine solution.

Incisions were made in the dorsum, and four subcutaneous pockets were carefully prepared by blunt dissection. The base of the pocket was more than $10 \mathrm{~mm}$ from the line of incision. In aseptic conditions, the tubes containing freshly mixed sealers were immediately implanted into the subcutaneous pockets. Each rat was implanted with four different sealers.

Care was taken to prevent smearing of the test material on the lateral sides of the tubes. Empty polytetrafluoroethylene tubes were used as the control. Finally the incisions were closed with $3 / 0$ silk sutures. The animals were maintained in cages on regular diet ad libitum. At the end of each period ( 1 , 2,4 , and 8 weeks) the animals were killed by an overdose of anesthetic solution. The dorsal skin was shaved and disinfected and the tubes were removed along with the surrounding tissues and immersed in 10\% buffered formalin $37 \%$ Formaldehyde, Merck Darmstadt, Germany).

After fixing for 48 hours, the tissue was processed for paraffin embedding and longitudinal serial sections were cut to a thickness of 6 um parallel to the tube. The sections were mounted on glass slides then stained with hematoxylin and eosin. Two independent examiners evaluated the specimens in a blind fashion in order to estimate the tissue response in the areas adjacent to the open ends of each tube. Each specimen was analyzed at different magnifications with a light microscope (Diastar, Cambridge Instruments, Buffalo, NY, USA)adapted to a video-camera (DXC-107A/107P; Sony Electronics,Tokyo, Japan). The sections were examined for the presence of inflammatory infiltrate, and fibrous capsule thickness, the latter being measured with Image Pro Plus for Windows, v.4.5 image -analysis software (Media Cybernetics, Silver Spring, MD, USA.)

Evaluation of the inflammatory reaction was carried out in three different areas of each section. An adaption of FDI criteria [27] and Campos-Pinto study [28] was used for evaluation of the H\&E sections for the presence or absence of inflammatory infiltrate (poly morphonuclear cells and mononuclear cells), macrophage activity (macrophage and giant inflammatory cells), mast cells, dispersed material and necrotic tissue. 


\begin{tabular}{|c|c|c|c|c|c|c|c|c|c|c|}
\hline & \multicolumn{5}{|c|}{ Control } & \multicolumn{5}{|c|}{ CPC-I } \\
\hline $\begin{array}{c}\text { Observation } \\
\text { Periods (week) }\end{array}$ & $\mathrm{Cll}$ & $\mathrm{N}$ & GC & $\mathrm{DM}$ & $\mathrm{N}$ & $\mathrm{Cll}$ & $\mathrm{N}$ & GC & $\mathrm{DM}$ & $\mathrm{N}$ \\
\hline 1 & $2 / 5+++\#$ & $2 / 5+++\#$ & $0 / 5$ & - & - & $2 / 5++* \#$ & $2 / 5++* \#$ & $0 / 5$ & - & - \\
\hline 2 & $2 / 5+++$ & $2 / 5+++$ & $0 / 5$ & - & - & $3 / 5+*$ & $0 / 5^{*}$ & $0 / 5$ & - & - \\
\hline 4 & $0 / 5^{\#}$ & $0 / 5$ & $0 / 5$ & - & - & $4 / 5+$ *\# & $0 / 5$ & $0 / 5$ & - & - \\
\hline \multirow[t]{2}{*}{8} & $0 / 5^{\#}$ & $0 / 5^{\#}$ & $0 / 5$ & - & - & $0 / 5^{\#}$ & $0 / 5^{\#}$ & $0 / 5$ & - & - \\
\hline & \multicolumn{5}{|c|}{ CPC-II } & \multicolumn{5}{|c|}{ Pulp canal sealer (PCS EWT) } \\
\hline $\begin{array}{c}\text { Observation } \\
\text { Periods (week) }\end{array}$ & $\mathrm{Cll}$ & $\mathrm{N}$ & GC & $\mathrm{DM}$ & $\mathrm{N}$ & CII & $\mathrm{N}$ & GC & DM & $\mathrm{N}$ \\
\hline 1 & $5 / 5+++* \#$ & $2 / 5+++^{*} \#$ & $5 / 5+++^{*} \#$ & $++^{*} \#$ & $++^{*}$ & $5 / 5+++* \#$ & $3 / 5+++^{*} \#$ & $5 / 5+++^{*} \#$ & $++^{*} \#$ & $+++^{*} \#$ \\
\hline 2 & $5 / 5+++*$ & $2 / 5+++$ & $5 / 5++*$ & $++^{*}$ & $++^{*}$ & $5 / 5+++*$ & $3 / 5+++^{*}$ & $5 / 5++*$ & $++^{*}$ & $+++^{*}$ \\
\hline 4 & $3 / 5+++^{*}$ & $3 / 5+++^{*}$ & $2 / 5++* \#$ & + & + & $3 / 5+++* \#$ & $3 / 5+++^{*}$ & $2 / 5++* \#$ & $+\#$ & $+\#$ \\
\hline \multirow[t]{2}{*}{8} & $3 / 5++* \#$ & $2 / 5++^{*}$ & $2 / 5++* \#$ & $-\#$ & $++^{*}$ & $0 / 5+\#$ & $0 / 5+\#$ & $0 / 5 \#$ & -\# & -\# \\
\hline & \multicolumn{5}{|c|}{ Sealapex } & & & & & \\
\hline $\begin{array}{c}\text { Observation } \\
\text { Periods (week) }\end{array}$ & $\mathrm{Cll}$ & $\mathrm{N}$ & GC & $\mathrm{DM}$ & $\mathrm{N}$ & & & & & \\
\hline 1 & $3 / 5+++^{*} \#$ & $3 / 5+++* \#$ & $2++/ 5^{\star} \#$ & - & $++^{*} \#$ & & & & & \\
\hline 2 & $4 / 5++^{*}$ & $2 / 5+++^{*}$ & $1++/ 5^{*}$ & - & $++^{*}$ & & & & & \\
\hline 4 & $3 / 5+* \#$ & $0 / 5+\#$ & $0+/ 5^{\star}$ & - & $-\#$ & & & & & \\
\hline 8 & $0 / 5 \#$ & $0 / 5 \#$ & $0 / 5 \#$ & - & $-\#$ & & & & & \\
\hline
\end{tabular}

${ }^{*} \mathrm{p}<0.01$ vs tested groups

${ }^{\#} \mathrm{p}<0.01$ vs observation periods

CIl: Chronic inflammatory infiltrate (Macrophages, Lymphocytes and Plasmocytes); N: Neutrophils; GC: Multinucleate foreign body giant cells; DM: Dispersed Material; N: Necrosis. The data are presented as number of positive animals for each analyzed parameter/ total number of animals. + mild, ++ moderate,+++ severe.

Table 2: Severity of subcutaneous connective tissue response to the implanted materials

A score was used to quantify the presence or absence of these events as follows; depending on these features, a grade from 1 to 4 was used to graduate the inflammatory reaction:

1. absent (-): no chronic inflammatory cells

2. slight (+): few inflammatory cells scattered in the connective tissue

3. moderate $(++)$ : a large number of inflammatory cells focally arranged

4. severe $(+++)$ : a large number of inflammatory cells diffused in connective tissue

The criteria for scoring the inflammatory tissue response are as follows:

Grade I (no inflammation): the thickness of the reaction zone is similar to or only slightly wider than the thickness along the side tube, with no inflammatory cells.

Grade II (slight): the thickness of the reaction zone is similar to or only slightly wider than the thickness along the side tube, with few inflammatory cells.

Grade III (moderate inflammation): an increased reaction zone in which macrophages, plasma cells, or both are present.

Grade IV (severe inflammation): an increased reaction zone in which macrophages plasma cells and occasional foci of neutrophil granulocytes, lymphocytes, or both are present.

The thickness of the fibrous capsule around the implanted materials was measured at all evaluation periods classified according to the following scores: 1 - absent; 2 - thin layer of collagen fibers around the material; 3 - thick layer of collagen fibers around the material. The results of the fibrous tissue thickness comparisons were analyzed using analysis of variance and multiple comparisons (Duncan's test). However, discontinuous data were analyzed statistically by non parametric ANOVA, while quantitative data were evaluated by one-way ANOVA. The significance level was set at $5 \%$ for all analyses). The material was considered as biocompatible if the severity of the connective tissue reaction decreased with time.

\section{Results}

All animals remained in good health during the whole implantation periods. Macroscopic examination at the implant sites revealed that wound healing was satisfactory and without infection at all evaluation periods. The connective tissue adjacent to the open end of the polyethylene tube was evaluated, and a descriptive analysis of the histological findings was made. The severity of tissue reaction to the implanted materials is shown in table 2. The thickness of the fibrous capsule formed around the implanted materials at the different evaluation periods is presented in table 3.

\begin{tabular}{|ccccc|c|}
\hline & \multicolumn{4}{c|}{ Thickness of Fibrous Capsules $(\mu \mathrm{m})$} \\
\cline { 2 - 6 } $\begin{array}{c}\text { Observation } \\
\begin{array}{c}\text { Periods } \\
\text { (week) }\end{array}\end{array}$ & Control & CPC-I & CPC-II & PCS EWT & Sealapex \\
\hline 1 & $2.10 \pm 0.211^{*}$ & $2.70 \pm 0.250^{*}$ & $1.50 \pm 0.06^{*}$ & $1.69 \pm 0.078^{*}$ & $1.90 \pm 0.250^{*}$ \\
2 & $3.50 \pm 0.420^{*}$ & $3.64 \pm 0.430^{*}$ & $2.40 \pm 0.20^{*}$ & $2.80 \pm 0.202^{*}$ & $2.92 \pm 0.430^{*}$ \\
4 & $4.13 \pm 0.511^{*}$ & $3.84 \pm 0.478^{*}$ & $3.20 \pm 0.388^{*}$ & $3.70 \pm 0.466^{*}$ & $3.82 \pm 0.478^{*}$ \\
8 & $2.53 \pm 0.214^{*}$ & $2.5 \pm 0.101^{*}$ & $4.80 \pm 0.610^{*}$ & $3.15 \pm 0.388^{*}$ & $2.90 \pm 0.101^{*}$ \\
\hline
\end{tabular}

${ }^{*} p>0.05$ vs tested groups

\# $\mathrm{p}<0.01$ vs tested groups

Table 3: The mean and standard deviation of thickness of fibrous capsules 


\section{Histopathologic results}

Control group: Histologic reaction around the empty polyethylene tube shows no inflammation from the $7^{\text {th }}$ day characterized by a thin fibrous capsule (Figures $1 \mathrm{~A}$ and $1 \mathrm{~B}$ ).
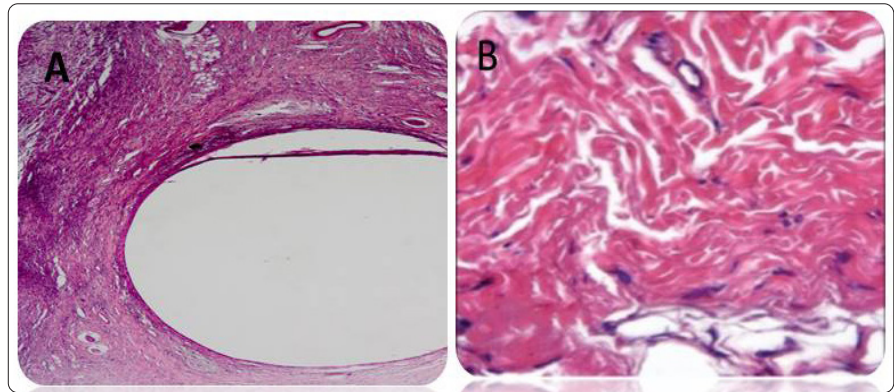

Figure 1: A thin fibrous capsule characterizes the control group(Ax40).No inflammation was observed from the $7^{\text {th }}$ day(Bx100)

\section{Experimental groups}

Histologic reaction around CPC-I (at 7 to 56 days): At 7 days a homogenous zone of granulation tissue exhibited moderate inflammatory infiltrate of polymorphonuclear leukocytes, macrophages and few hyperemic dilated blood vessels (Figures $2 \mathrm{~A}$ and $2 \mathrm{~B}$ ).

At 14 days: A mild chronic reaction predominantly formed of lymphocytes with an initial delicate capsular organization was observed (Figures 2C and 2D).

At 28 days: In this period there was a mild to absent chronic inflammatory reaction around CPC-I and Sealapex and the establishment of a fibrous capsule is evident (Figures 2E and 2F).

At 56 days: CPC-I, PCS EWT and Sealapex presented histological features similar to those at 28 days with mild to absent chronic inflammatory reaction, without foreign body giant cells or macrophages. No necrosis or any degenerative changes were observed. The group of sealers exhibited a fibrous capsule with high amounts of cell and vessels (Figures $2 \mathrm{G}$ and $2 \mathrm{H}$ ).

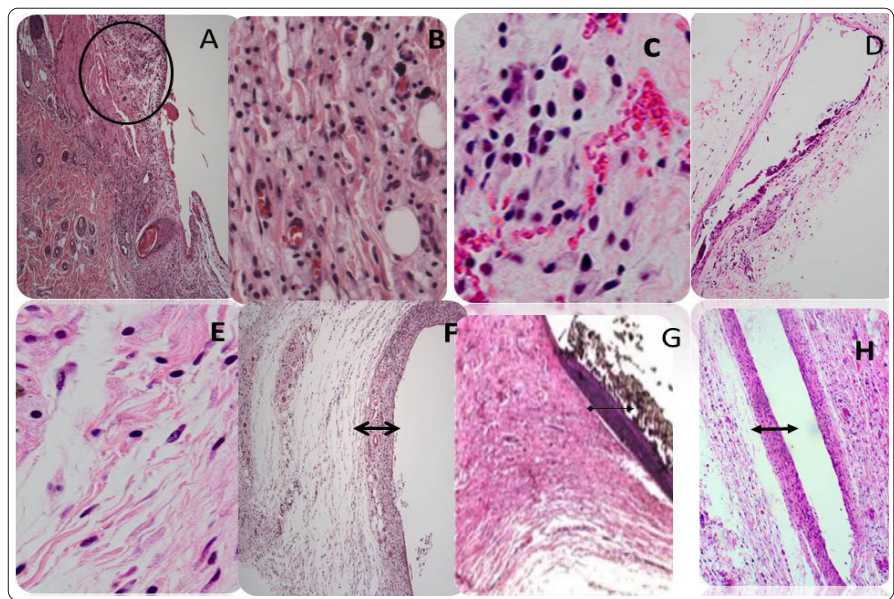

Figure 2: Histologic reaction around CPC-I 7 days a homogenous zone of granulation tissue circle (Ax40) exhibiting moderate inflammatory infiltrate and dilated blood vessels(Bx100); CPC-I

14days a mild lymphocytic infiltrate(Cx100); a thin fibrous capsule (Dx40); CPC-I, Sealapex and PSC EWT 28\&56 days mild inflammatory infiltrate (Ex40) note the absence of inflammation (Fx100). Fibrous capsule formation (arrows) evident in all groups ( $\mathrm{F}, \mathrm{G}, \mathrm{H} \times 40)$
Histologic reaction around CPC-II (at 7 to 56 days): At 7 days a severe inflammatory reaction predominantly formed of lymphocytes, macrophages associated with areas of residual dispersed amorphous black material and foreign body giant cell were noted (Figures $3 \mathrm{~A}$ and $3 \mathrm{~B}$ ).

At 14 days: CPC-II and PCS EWT presented a severe inflammatory reaction (Figures $3 C$ and $3 D$ ) with foreign body giant cells in addition to small foci of necrosis which were more evidently seen in the PCS EWT group (Figures $3 \mathrm{E}$ and $3 \mathrm{~F}$ ).

At 28 days: CPC-II and PCS EWT groups were still histologically similar showed a chronic lymphocytic inflammatory infiltrate. In addition to macrophages and dispersed blood (Figure 4C). A cellular reaction characterized by the presence of multinucleated giant cells with engulfed particles of the material was seen in these specimens (Figure 4D).

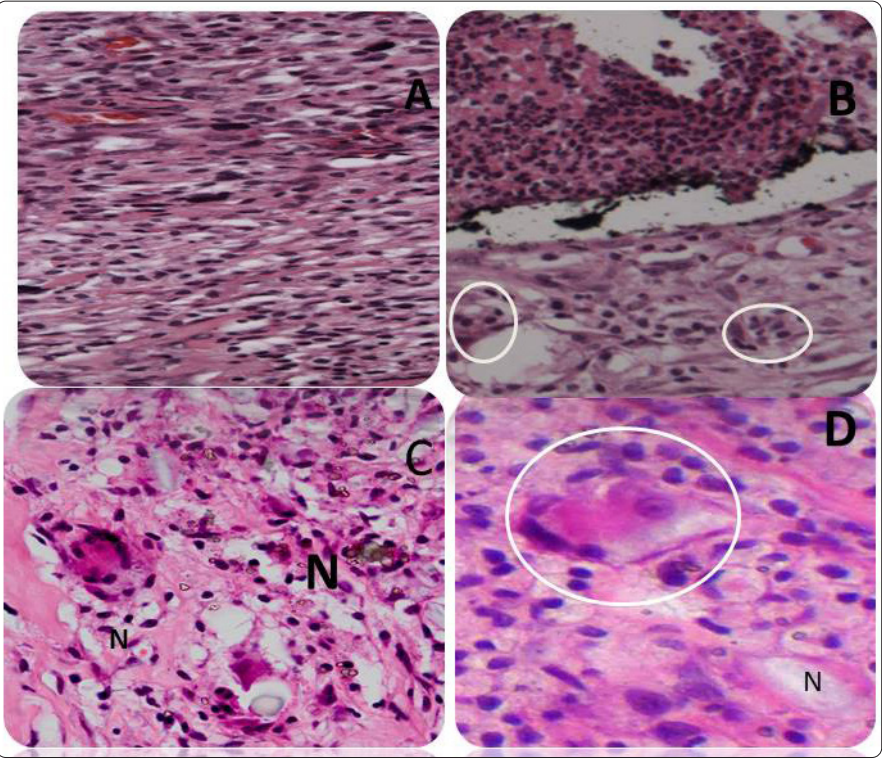

Figure 3: Histologic reaction around CPC-II 7 days severe inflammatory infiltrate $(A \times 40)$ with the presence of lymphocytes and multinucleated giant cells(circle)(Bx100); CPC-II 14 \&28 days moderate inflammatory infiltrate Note marked presence of macrophages $(\mathrm{Cx} 40)$ foreign body giant cells(circle) with considerable small foci of necrosis(N)) in the PSC EWT specimens(Dx100)

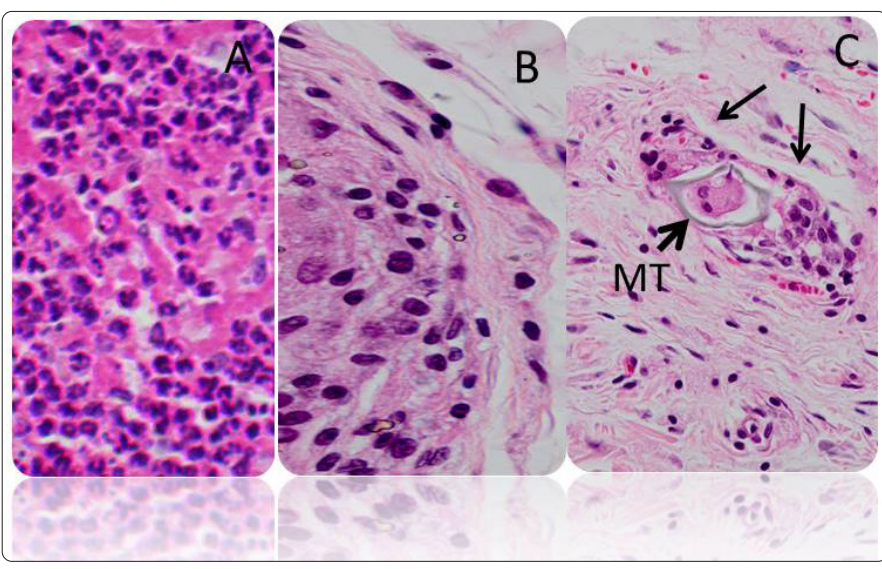

Figure 4: Histologic reaction of CPC-II 56 days persisting moderate inflammatory infiltrate of neutrophilic leucocytes (Ax40) lymphoplasmocytic infiltration(Bx100) with presence of apoptotic giant cells(arrows) adjacent to dispersed residual material(MT) (Cx100). 
At 56 days: CPC-II presented a persisting moderate inflammatory reaction of neutrophilic leukocytes, lymphoplasmacytic infiltration together with persistence of macrophages (Figures 5A and 5B). Apoptotic giant cells were also noted encompassing the residual dispersed sealer (Figures 5C and 5D).

In all analyzed periods significant difference on biocompatibility among the groups was observed CPC-II sealer did not show a decreased in the inflammatory reaction over time. There were highly significant differences in tissue reaction between CPC-I group and CPC-II, PCS EWT, Sealapex and the control groups during the first two observation periods $(p<0.01)$. In addition, there were highly significant differences between CPC-II group and CPC-I, PCS EWT, Sealapex and the control groups during the last two observation periods $(p<0.01)$. Highly significant differences were present among observation periods within all tested groups (1, 2, 4, and 8 weeks).

The presence of giant cells was significantly higher in the CPC-II group at the first three observation periods with a statistically significant difference $(p=0.0002)$ when compared to CPC-I.

Regarding fibrous tissue thickness presented in Table3, there was no statistically significant difference between the control groups, CPC-I, CPC-II, and PCS EWT and Sealapex groups for the first three observation periods $(p>0.05)$. However, there was highly significant differences between the control groups, CPC-I, CPC-II, and PCS EWT and Sealapex groups during the last observation period ( 8 weeks) $(p<0.01)$. The control group (empty tube) had the thinnest $(p<0.01)$ fibrous capsule formed among the implanted materials.

\section{Discussion}

The field of endodontics, especially as regards the materials and techniques, has been presenting considerable advances in the last years, providing the professionals with greater safety for accomplishment of root canal filling. Different filling materials with diverse chemical components have been tested in the search for a substance that presents ideal physicochemical and biological properties for a perfect root canal sealing $[29,30]$.

Recommended tests for biocompatibility of endodontic materials include local toxicity testing by subcutaneous [31] or intraosseous implantation of [32] materials in laboratory animals [33].

Although cell culturing methods give some valuable information about the response of specific cells to a test material, they do not provide the full picture of how a tissue reacts to the material under in vivo conditions [34]. In vivo implantation experiments provide more complete and clinically relevant information on the long - term tissue response [35].

The development of scientific knowledge in medical and related areas has long been employing animal investigations. The frequent utilization of rats as a research tool is based on aspects such as easy handling, relatively short vital cycles, and well-known anatomy, physiology and genetic variations [36].
Subcutaneous connective tissue implantation in animals is one of the most reliable methods of evaluating biocompatibility of dental materials. The toxic and inflammatory reactions in subcutaneous tissues against materials are thought to be characteristic features for all connective tissues $[37,38]$.

Tissue reaction to the tested materials was studied at 1,2 , 4 , and 8 weeks and there connective tissue response evaluated, as measured by inflammatory reaction intensities and fibrous capsule thickness.

In the present study, the inflammatory reactions of the control group and all tested materials CPC- I, CPC-II, Seal apex, and PCS EWT at 1 week were more severe than at 2 week and 4 week. This condition is expected to be partly caused by the surgical trauma produced during the placement of the tubes in addition to the toxic effects of the implanted material and the tube material itself [39]. At this time, the tissue was disorganized and infiltrated with neutrophils, which is consistent with the findings of other studies [40].

The inflammatory reaction for CPC-I sealer, however had diminished (become milder) by week 2. A stronger action of the sealers in the beginning and attenuation of the inflammatory response over time had been reported elsewhere [41-43]. The results of this study concur with these studies after the 2 week period.

The response of tissue to the effects of CPC-I was examined at 1, 2, 4 and 8 weeks. Week -1 results of the tested materials revealed severe inflammatory responses, but these had subsided by week 8 .

On the other hand, CPC-II initially evoked severe inflammation accompanied by foreign body reaction, however a persistent moderate chronic inflammation and high phagocytic activity around CPC-II were observed at 4 , and 8 weeks post implantation. CPC-II was found to be causing more inflammatory response compared to CPC-I, and PCS EWT. The presence of giant cells was noted in the CPC-II group at the observation periods 2 and 4 weeks, with a statistically significant difference $(p=0.0002)(p<0.01)$ from CPC-I. This may be attributed to the consistency of CPC-II, which demonstrated detachment of small particles from the main material mass into the surrounding tissue, evoking a foreign body reaction. Giant cells are known to participate in the organism reaction to foreign bodies and are associated with the presence of material that the body finds hard to break down.

CPC-II sealer demonstrated a slow breakdown, illustrated by the dispersed material, and subsequent endocytosis by the foreign body giant cells which might have been the cause of the persistent chronic inflammation. Therefore, most of the leached components of the material including soluble ions or molecules, insoluble wear debris and fragments may be displaced at a distance from the implantation site. Small particles evoke an intense localized inflammatory reaction, characterized by the presence of multinucleated giant cells and macrophages which in turn release inflammatory kinins like fibroblast growth factor and platelet derived growth factor that influence fibroblast behavior and subsequently 
induce thickening of the fibrous capsule [44-47]. Similar histological features were observed in the present investigation suggesting that the cement particles, released into the wet environment after the implantation procedure, triggered a persistent local chronic inflammatory response.

CPC-II sealer elicited the presence of lymphoplasmacytic infiltrate plus the pronounced number of macrophages in the 8 week period in the connective tissue suggesting that the inflammatory reaction is longer-lasting and more intense. Additionally, the observed increasingly thickened fibrous connective tissue capsule forming around the tested samples of CPC-II sealer and the statistical comparisons revealed that there were significant differences for fibrous tissue thickness between 1, 4, and 8 weeks respectively. At the 8 weeks period, there was a marked increase in the thickness of fibrous connective tissue around the tested material that suggests that the material was not well tolerated by the tissue. The difference in inflammatory response for CPC-II sealer among the tested materials is related to a number of factors including the variation in chemical composition and the quantity of chemotoxic leachables migrating from the un reacted poly acrylic acid which has a low $\mathrm{pH}$ and may leak gradually to the surrounding humid connective tissue during the setting process [48].

Also, it has been reported that the slow acid/base reaction that occurs in calcium phosphate cements causes the maintenance of the low $\mathrm{pH}$ of the material for extended periods of time [49]. Therefore, the persistently low $\mathrm{pH}$ of the set calcium phosphates in contact to the connective tissue seems to play an important role in the local connective tissue damage, following the implantation procedure.

The inflammatory reactions for PCS EWT showed that the material created a severe inflammatory response initially, which decreased by 8 weeks period. The PCS EWT was more irritating than the other sealers over the initial experimental periods studied. The PCS EWT caused considerable necrosis in some cases at the first two test periods, in comparison with CPC-II which caused mild necrosis in a few cases.

Pulp Canal sealer EWT is zinc-oxide-and -eugenol (ZOE) based sealer and has residual eugenol after mixing. Eugenol (4- allyl- 2 methoxy phenol) is an extract of clove oil widely used in industry as a therapeutic agent, most commonly used as a component of ZOE cement applied as a base or temporary dressing to dentin or as a root canal sealer [50]. Several studies have been reported on the histopathologic influence of ZOE-based root canal sealers on tissues [51,52]. Pulp canal sealer PCS EWT brought about greater quantities of macrophages. De Oliveira Mendes et al [53]. Assessed the effects of zinc-oxide eugenol sealers and concluded that they did not interfere with the macrophages viability, but adherence and potential for phagocytosis was affected. This explains the increased mobilization of macrophages to cope with the potential for tissue irritation.

As previously stated [54], this residual eugenol ( 5\%) is sufficient to cause an inflammatory reaction. This could be attributed to eugenol release from this material whose content is high right after mixing, but decreases with time. Thus, leaching of eugenol into the nearby humid connective tissue environment may explain the higher incidence of necrosis with PCS EWT implants, especially at the initial assessment period, with the effects becoming milder as the toxic material is neutralized and removed by local lymphatic drainage.

Many investigators have suggested that it's irritative ability could be attributed primarily to eugenol and secondarily to zinc ions $[55,56]$. Eugenol can inhibit the macrophage function and may influence the inflammatory reactions in the periapical tissues [57].

Several studies with ZOE- based obturating materials have shown that the intensity of the inflammatory response is directly related to the powder liquid/ratio used and that the quantity of free eugenol depends on the mixtures' consistency during hardening [58].

In the present study, the subcutaneous tissue inflammatory reactions to PCS EWT decreased with time similar to the results obtained by Filho et al. [59], probably owing to the neutralization of the eugenol liberated at the start [60]. The response of the tissue to the effects of Pulp Canal sealer EWT revealed severe inflammatory response, but these had subsided by the 8 weeks period.

The inflammatory reactions for Sealapex showed that the material created a severe inflammatory response initially, which decreased by 4 weeks period. Sealapex is based on calcium hydroxide. Sealers containing calcium hydroxide will be biologically active when calcium and hydroxide ions are released [61].

The diffusion of hydroxyl ions from the root canal sealers increases the $\mathrm{pH}$ at the root surface adjacent to the periodontal tissues, favoring the repair. Sealers based on calcium hydroxide are used to enhance the healing process. These results are in accordance with Gomes-Filho et al. [62] and Silveira et al. [63] in which mild to moderate inflammatory reaction to Sealapex was elicited at 7 days, decreasing at the subsequent evaluation periods.

The results of the histometric evaluation indicate that the least favorable tissue reaction was observed with CPC-II sealer. However, the inflammatory responses caused by CPC-I, and PCS EWT, and Sealapex were acceptable at the 8 weeks period demonstrating that they were well tolerated by the tissues. The inflammatory reaction was severe during the first experimental period, and finally after 8weeks, a picture of total healing was observed. On the contrary CPC-II, initially caused severe inflammation of the adjacent tissues, and a moderate chronic inflammation remained after 8weeks.

Among the three sealers, CPC-I presented the best biological behavior for all periods, followed by Sealapex and PCS EWT, showing an initial irritating effect. CPC-II caused the highest degree of irritation, producing a prolonged moderate inflammatory reaction. 


\section{Conclusion}

Biocompatibility is as important as the physical and chemical features when selecting a material for root canal filling because of direct contact with vital tissues. Within the limitations of this in vivo study, it can be concluded that CPC-I sealer yielded a satisfactory tissue reaction, can be assigned a favorable biocompatibility level based on the study's histological findings in the subcutaneous tissue of rats.

Conflicts of Interest: The authors declare no conflicts of interest with this submission.

\section{References}

1. Waltimo TM, Boiesen J, Eriksen HM, Orstavik D. Clinical performance of 3 endodontic sealers. Oral Surg Oral Med Oral Pathol Oral Radiol Endod. 2001; 92(1): 89-92. doi: 10.1067/moe.2001.116154

2. Pommel L, Camps J. In vitro apical leakage of system B compared with other filling techniques. J Endod. 2001; 27(7): 449-451. doi: 10.1097/00004770-200107000-00003

3. Koppang HS, Koppang R, Stolen SO. Identification of common foreign material in postendodontic granulomas and cysts. J Dent Assoc S Afr. 1992; 47(5): 210-216.

4. Hauman $\mathrm{CHJ}$, Love RM. Biocompatibility of dental materials used in contemporary endodontic therapy: A review, part 2: Root canal filling materials. Int Endod J. 2003; 36(3): 147-160.

5. Cençoĝlu N, Turkmen C, Ahiskali R. A new silicon -based root canal sealer (Roekoseal-Automix). J Oral Rehabil. 2003; 30(7): 753-757.

6. Bouillageut $\mathrm{S}$, Wataha $J C$, Lockwood $\mathrm{PE}$, et al. Cytotoxicity and sealing properties of four classes of endodontic sealers evaluated by succinic dehydrogenase activity and confocal laser scanning microscopy. Eur $J$ Oral Sci. 2004; 112(2): 182-187. doi: 10.1111/j.1600-0722.2004.00115.x

7. Zmener $\mathrm{O}$, Banegas $\mathrm{G}$, Pameijer $\mathrm{CH}$. Bone tissue response to a methacrylate-based endodontic sealer: A histological and histometric study. J Endod. 2005; 31(6): 457-459.

8. Huang $\mathrm{TH}$, Yang JJ, Li $\mathrm{H}$, Kao CT. The biocompatibility evaluation of epoxy-resin based root canal sealers in vitro. J Biomater. 2002; 23(1): 7783. doi: 10.1016/S0142-9612(01)00081-3

9. Veloso HH, Santos RA, Araujo TP, Leonardi DP, Baratto FF. Histological analysis of the biocompatibility of three different sealers. J Appl Oral Sci. 2006; 14(5): 376-381.

10. Gomes FJE, Bernabe PFE, Nery MJ, et al. Reaction of rat connective tissue to a new calcium hydroxide based sealer. Oral Med Oral Radiol Endod. 2008; 106: e71-e76. doi: 10.1016/j.tripleo.2008.03.030

11. Sari S, Okte Z. Success rate of Sealapex in root canal treatment for primary teeth: 3 year follow up. Oral Surg Oral Med Oral Pathol Oral Radiol Endod. 2008; 105(4): e93-e96. doi: 10.1016/j.tripleo.2007.12.014

12. Molloy D, Goldman M, White RR, Kabani S. Comparative tissue tolerance of a new endodontic sealer. Oral Surg Oral Med Oral Pathol. 1992; 73(4): 490-493.

13. Leonardo MR, Barnett F, Debelian GJ, Lima RCP, Silva LAB. Root canal adhesive filling in dogs with or without coronal restoration: A histopathological evaluation. J Endod. 2007; 33(11): 1299-1303. doi: 10.1016/j.joen.2007.07.037

14. Yuan H, Li Y, de Bruijn JD, de Grook, Zhang X. Tissue responses of calcium phosphate cement: a study in dogs. J Biomater. 2000; 21(12): 1283-1290. doi: 10.1016/S0142-9612(00)00016-8

15. Wataha JC. Principles of biocompatibility for dental practitioners. Prosthet Dent. 2001; 86(2): 203-209. doi: 10.1067/mpr.2001.117056

16. Hong CY, Lin SK, Kok SH, Wong MY, Hong Y. Histiological reaction to a newly developed calcium phosphate cement implanted in the perapical and periodontal tissues. J Formos Med Assoc. 1990; 89(4): 297-304.
17. Fukase Y, Eanes ED, Tagaki S, Chow LC, Brown WE. Setting reaction and compressive strength of calcium phosphate cements. J Dent Res. 1990; 69(12): 1852-1856.

18. Yoshikawa M, Hatami S, Tsuji I, Toda T. Histopathological study of a newly developed root canal sealer containing tetracalcuim- dicalcuim phosphates and 1\% chondroitin sulfate. J Endod. 1997; 23(3): 162-66. doi: 10.1016/S0099-2399(97)80267-1

19. Geurtsen W. Biocompatibility of root canal filling materials. Aust Endod J. 2001; 27(1): 12-21

20. Ozabas $H$, Yaltirik M, Bilgic B, Issever $H$. Reactions of connective tissue to compomers, composite and amalgam root-end filling materials. Int Endod J. 2003; 36(4): 281-287.

21. Bernath $\mathrm{M}$, Szabo J. Tissue reaction initiated by different sealers. Int Endod J. 2003; 36(4): 256-261.

22. KhashabaR, Moussa M, Mettenburg D, et al. Polymeric-Calcium Phosphate Cement Composites-Material Properties: In Vitro and In Vivo Investigations. Int J Biomater. 2010; 691452. doi: 10.1155/2010/691452

23. Ho Y-C, Huang F-M, Chang Y-C. Mechanisms of cytotoxicity of eugenol in human osteoblastic cells in vitro. Int Endod J. 2006; 39(5): 389-393. doi: 10.1111/j.1365-2591.2006.01091.x

24. Modaresi J, Yavaris A, Dianat SO, Shahrabi S. A comparison of tissue reaction to MTA and an experimental root-end restorative material in rats. Aust Endod J. 2005; 31(2): 69-72.

25. Sousa CJ, Loyola AM, Versiani MA, Biffi JC, Oliveira RP, Pascon EA. A comparative histological evaluation of the biocompatibility of materials used in perapical surgery. Int Endod J. 2004; 37(11): 738-748. doi: 10.1111/j.1365-2591.2004.00861.x

26. Stanford JW. Recommended standard practices for biological evaluation of dental materials. Fédération Dentaire International, Commission of Dental Materials, Instruments, Equipment and Therapeutics. Int Dent J. 1980; 30(2): 141-88.

27. de Campos-Pinto MMD, de Oliveira DA, Versiani MA, Silva-Sousa YTC, Manoel Damião de Sousa-Neto MD, da Cruz Perez DE. Assessment of the biocompatibility of Epiphany root canal sealer in rat subcutaneous tissues. Oral Surg Oral Med Oral Pathol Oral Radiol Endod. 2008; 105(5): e77-81. doi: 10.1016/j.tripleo.2008.01.024

28. National Institutes of Health. Public Health Service policy on human care and use of laboratory animals, 2006.

29. Zmener O. Tissue response to a new methacrylate-based root canal sealer: preliminary observations in the subcutaneous connective tissue of rats. J Endod. 2004; 30(5): 348-351. doi: 10.1097/00004770-20040500000010

30. Bhambhani SM, Bolanos OR. Tissue reactions to endodontic materials implanted in the mandibles of guinea pigs. Oral Surg Oral Med Oral Pathol. 1993; 76(4): 493-501. doi: 10.1016/0030-4220(93)90019-Z

31. Sundqvist G, Figdor D. Endodontic treatment of apical periodontitis. In: Ørstavik D, Pittford TR (eds). Essential Endodontology, 5th edition. Oxford: Blackwell Scientific Publications. 2003: 242-277

32. Langeland K. Correlation of screening tests to usage tests. J Endod. 1971; 4(10): 300-303. doi: 10.1016/S0099-2399(78)80276-3

33. Veloso H, Do Santos RA, De Araújo T, Leonardi D, Filho F. Histological analysis of the biocompatibility of three different calcium hydroxidebased root canal sealers. J App Oral Sci. 2006; 14(5): 376-381.

34. Zmener O, Guglielmotti MB, Cabrini RL. Biocompatibility of two calcium hydroxide- based endodontic sealers: a quantitative study in the subcutaneous connective tissue of the rat. J Endod. 1988; 14(5): 229-235. doi: 10.1016/S0099-2399(88)80175-4

35. Spangberg L, Langeland K. Biological effects of dental materials. Oral Surg Oral Med Oral Pathol Oral Radiol Endod 1973; 36(6): 402-414.

36. Kolokuris I, Beltes P, Economides N, Vlemmas I. Experimental study of the biocompatibility of a new glass-ionomer root canal sealer (Ketac-Endo). $J$ Endod. 1996; 22(8): 395-398. doi: 10.1016/S0099-2399(96)80237-8 
37. Gomes BP, Pedroso JA, Jacinto $\mathrm{RC}$, et al. In vitro evaluation of the antimicrobial activity of five root canal sealers. Braz Dent J. 2004; 15(1): 30-35. doi: 10.1590/S0103-64402004000100006

38. van der Meulen J, Koerten HK. Inflammatory response and degradation of three types of calcium phosphate ceramic in a non osseous-environment. J Biomed Mater Res. 1994; 28(12): 1455-1463. doi: 10.1002/jbm.820281211

39. Yuan HP, Yang ZJ, Li Y, Zhang XD, De Bruijn JD, De Groot K. Osteoinduction by calcium phosphate biomaterials. J Mater Sci Mater Med. 1998; 9(12): 723-726.

40. Comuzzi L, Ooms E, Jansen JA. Injectable calcium phosphate cement as a filler for bone defects around oral implants: an experimental study in goats. Clin Oral Implants Res. 2002; 13(3): 304-311.

41. Miyazaki K, Horibe T, Antonucci JM, Takagi S, Chow LC. Polymeric calcium phosphate cements: analysis of reaction products and properties. J Dent Mater. 1993; 9(1): 41-45.

42. Safavi KE, Pascon EA, Langland $K$. Evaluation of tissue reaction to endodontic materials. J Endod. 2002; 28: 749-753.

43. Bohner $M$, Van Landuyt $P$, Merkle HP, Lemaitre J. Composition effects on the $\mathrm{pH}$ of a hydraulic calcium phosphate cement. J Mater Sci Mater Med. 1997; 8(11): 675-681.

44. Tepel J, Darwisch el Sawaf M, Hoppe W. Reaction of inflamed periapical tissue to intracanal medicaments and root canal sealers. Endod Dent Traumatol. 1994; 10(5): 233-238.

45. Holland R, Filho JAO, Bernabe PFP, Nery MJ, de Souza V, Berbert A. Effect of root canal status on periodontal healing after surgical injury in dogs. $J$ Endod Dent Traumatol. 1994; 10(2): 77-82.

46. de Oliveira Mendes ST, Ribeiro Sobrinho AP, de Carvalho AT, de Souza Cortes MI, Vieira LQ. In vitro evaluation of the cytotoxicity of two root canal sealers on macrophage activity. J Endod. 2003; 29(2): 95-99.

47. Molnar EJ. Residual eugenol from oxide- eugenol compounds. J Dent Res. 1967; 46(4): 645-649.

48. Neff T, Layman D, Jeansonne BG. In vitro cytotoxicity evaluation of endodontic sealers exposed to heat before assay. J Endod. 2002; 28(12): 811-814. doi: 10.1097/00004770-200212000-00005

49. Ioannis K, Nikolaos E. In vivo comparison of the biocompatibility of two root canal sealers implanted into the subcutaneous connective tissue of rats. J Endod. 2002; 24(2): 82-85. doi: 10.1016/S0099-2399(98)80082-4

50. Gomes-Filho JE, Gomes BP, Zaia AA, Ferraz CR, Souza-Filho FJ. Evaluation of the biocompatibility of root canal sealers using subcutaneous implants. J Appl Oral Sci. 2007; 15(3): 186-194.
51. Gulati N, Chandra S, Aggarwal PK, Jaiswal JN, Singh M. Cytotoxicity of eugenol in sealer containing zinc-oxide. J Endod Dent Traumatol. 1991; 7(4): 181-185

52. Estrela C, Sydney GB, Bammann LL, Felippe Junior O. Mechanism of action of calcium and hydroxyl ions of calcium hydroxide on tissue and bacteria. Braz Dent J. 1995; 6(2): 85-90.

53. Silveira CMM, Pinto SCC, Zedebski RAM, Santos FA, Pilatti GL. Biocompatibility of four root canal sealers: a histopathological evaluation in rat subcutaneous connective tissue. Braz Dent J. 2011; 21: 21-27.

54. Mittal M, Chandra S, Chandra S. Comparative tissue toxicity evaluation of four endodontic sealers. J Endod. 1995; 21(12): 622-624. doi: 10.1016/ S0099-2399(06)81116-7

55. Maseki T, Nakata K, Kohsaka T, Kobayashi F, Hirano S, Nakamura H. Lack of correlation between the amount of eugenol released from zinc oxideeugenol sealer and cytotoxicity of the sealer. J Endod. 1991; 17(2): 76-79. doi: 10.1016/S0099-2399(06)81612-2

56. Markowitz K, Moynihan M, Liu M, Kim S. Biologic properties of eugenol and zinc oxide-eugenol. A clinically oriented review. Oral Surg Oral Med Oral Pathol. 1992; 73(6): 729-737.

57. Farid F, Mahgoli H, Hosseini A, Chiniforush N. Effect of eugenol-containing and resin endodontic sealers on retention of prefabricated metal posts cemented with zinc phosphate and resin cements. J Prosthodont Res. 2013; 57(4): 284-287. doi: 10.1016/j.jpor.2013.08.002

58. da Silva PT, Pappen FG, Souza EM, et al. Cytotoxicity evaluation of four endodontic sealers. Braz Dent J. 2008; 19(3): 228-231.

59. Gomes-Filho, Cristina Gomes, Simone Watanabe, et al. Evaluation of tissue reaction, cell viability and cytokine production induced by Sealapex Plus. $J$ Appl Oral Sci. 2011; 19(4): 329-36. doi: 10.1590/S1678-77572011005000006

60. Lodiene G, Morisbak E, Bruzell E, Ørstavik D. Toxicity evaluation of root canal sealers in vitro. Int Endod J. 2008; 41(1): 72-77. doi: 10.1111/j.1365-2591.2007.01321.x

61. Silva EJ, Santos CC, Zaia AA. Long-term cytotoxic effects of contemporary root canal sealers. J Appl Oral Sci. 2013; 21(1): 43-47.

62. Gomes-Filho, Bernabé PF, Nery MJ, et al. Reaction of rat connective tissue to a new calcium hydroxide-based sealer. Oral Surg Oral Med Oral Path Oral Radiol Endod. 2008; 106(2): e71-e76. doi: 10.1016/j.tripleo.2008.03.030

63. Silveira CM, Pinto SC, Zedebski Rde A, Santos FA, Pilatti GL. Biocompatibility of Four Root Canal Sealers: A Histopathological Evaluation in Rat Subcutaneous Connective Tissue. Braz Dent J. 2011; 22(1): 21-27. 